\title{
Stagnation of Rice Straw Agribusiness Development in Malaysia: The Entrepreneurs' Perspectives
}

\author{
Rosmiza MZ \\ Universiti Kebangsaan Malaysia; Royal Agricultural University, United Kingdom; Email: miza@ukm.edu.my \\ Davies, WP \\ Royal Agricultural University, United Kingdom \\ Rosniza Aznie CR \\ Universiti Kebangsaan Malaysia \\ Jabil MJ \\ Universiti Malaysia Sabah \\ Mazdi M \\ Universiti Pendidikan Sultan Idris \\ Wan Toren WY \\ Brunel University London, United Kingdom \\ Che Rosmawati CM \\ Brunel University London, United Kingdom
}

Doi:10.5901/mjss.2015.v6n4p523

\section{Abstract}

Given the need to address the adverse environmental impacts of rice straw burning, enhancing straw-utilisation would seem to be a step in the right direction. One way to achieve this objective would be to develop viable straw entrepreneurs. This study evaluates the barriers and challenges facing the straw entrepreneurial development in Malaysia. A total of 44 entrepreneurs in the country's rice bowl areas of MADA $(n=24)$ and Sekinchan $(n=20)$ were interviewed. The findings reveal five major problems that have been stagnating the Malaysian straw agribusiness, namely, lack of support from both authorities and the community, lack of research and access to technology facilities, low levels of skills and knowledge pertaining to straw industry, and lack of readily available venture capital. Other related challenges unveiled include uncertain entrepreneurial attitude, limited product markets, unreliable supply of raw straw, and the lack of skilled workers. To reverse the stagnation and rejuvenate its straw byproduct agribusiness Malaysia would need to strengthen and integrate institutional support, to enlarge all round stakeholders' involvement including that of the local community and the entrepreneurs themselves, and embark on fullscale product and market development.

Keywords: by-product, agribusiness, entrepreneur, rice straw, sustainable entrepreneurship

\section{Introduction}

In Asia, straw is mostly managed through on-field burning or left on the field. Sometimes, straw may be removed from fields for livestock bedding and feeding; household energy; and off-field purposes (Rosmiza et al. 2014; Bijay-Singh et al. 2008). Open-burning of straw is a controversial practice following harvesting. This method is the cheapest and easiest way of land preparation for the next cultivation season. Burning straw is also done, however, to eliminate pests, weeds and disease challenges (Rosmiza et al. 2014; MADA 2010; Zhang and Jenkins 2004). Unfortunately, greenhouse gases (GHGs) such as carbon monoxide, carbon dioxide, sulphur dioxide, nitrous oxide, dust and particulate matter are also substantially emitted by burning straw (Ministry of Economic Affairs 2013; Bhattacharya 2012; Gupta et al. 2004). As a result, it can significantly contribute to environmental pollution problems that are also threatening global climate change (Bhattacharya 2012; Indian Agricultural Research Institute, 2012; Vianaa et al. 2008; Gupta et al. 2004). Burning also has the effect of heating the soil surface and influencing soil fertility (Gupta et al. 2004); and human respiratory disease (Henderick and Williams 2000). Incomplete straw combustion also reportedly produces carbon monoxide and carcinogenic hydrocarbons which could perhaps cause some cancers (Bijay-Singh et al. 2008; Henderick and Williams 2000). 
There is enormous potential for various industrial developments and alternative energy sources if straw could be better utilised and exploited. A smarter economy should be introduced to minimise straw waste and to re-use straw as a valuable resource. Shifting from straw open-burning and traditional straw management to agribusiness development would be much more economically, agronomic and environmentally attractive for future straw disposal. To build-up possible industrial chains with other sectors would seem the most profitable approach to such agribusiness development. The 'waste-to-wealth' concept may support a much more environmentally-friendly approach for straw disposal and increased eco-efficiency (Rofina Yasmin and Subha Bhassu n.d). A growing body of research is needed, therefore, to analyse the barriers and challenges for entrepreneurs of better utilising straw for future agribusiness opportunities.

\section{Towards Sustainable Entrepreneurship in Straw Management}

Entrepreneurial success relies on the ability of an entrepreneur to grab opportunities in the marketplace; to create more product value and support personal change through hard work; enhancement of skills and expertise (Uddin and Bose 2013). Individual desires (Keogh and Polonsky 1998); demographic characteristics (age, gender, education and experience) of entrepreneurs; and environmental elements are also considered vital keys for successful entrepreneur development (Ahammad and Syed Moudud-ul-Huq 2013; Chowdhury 2013; Uddin and Bose 2013). A few studies profiling the demographic of who might become entrepreneurs reveals that they are likely to be more creative, innovative and actively looking for product uniqueness. While the business environment elements could include suitable marketing strategies; government incentives; bureaucratic barriers; technology-change opportunities; capital access; more adequate infrastructure facilities; better entrepreneurial training, and greater information access (Ahammad and Syed Moudud-ulHuq 2013; Chowdhury et al. 2013; Uddin and Bose 2013; Ahmad and Xavier 2012); market forces; and internal management issues remain important (Keogh and Polonsky 1998).

The Global Entrepreneurship Monitor (GEM) programme in South Africa identified a set of three strong characteristics in their early stages of business development grounded in social, political and economics in Society (Herrington and Kew 2013). While creating more unique business and entrepreneurial contexts; suitable supporting innovation and other entrepreneurship factors also need to be emphasized. The GEM model highlighted an entrepreneurship framework with conditions which include entrepreneurial capital; education; government policies and supporting programmes; research and development transfer; commercial, physical, and legal infrastructure; an openly internal market; and an encouraging cultural environment (Herrington and Kew 2013).

In Africa, there are several reported constraints for agribusiness development including inconsistent policies; limited access to farm land with community land rights; poor infrastructure and high costs of transportation; and less access to technologies, information, skills and finance (Bergh 2013; World Bank 2013). Entrepreneurs also reportedly have difficulties securing finance from institutions and investors, primarily directed towards more high impact, profitable business by-products and existing well-developed entrepreneurs (Bergh 2013).

According to Pastakia (1998), agri-entrepreneurs can often also have problems in creating a market demand for using more 'green' products. Consumer resistance and trust is sometimes challenged of using products such as agricultural inputs, technology, consumption patterns, and lifestyle. Unless, the green products convince consumers through appropriate pricing, high quality, uniqueness, and convenience they are unlikely to be adopted. The challenges can also come from a restrictive legal environment; absence of suitable regulation; lack of incentives; (Zhang and Jenkins 2004; Keogh and Polonsky 1998); and educating potential users (Ahammad and Syed Moudud-ul-Huq 2013). In dealing with this, entrepreneurs could change their strategy through better marketing of the concept; in impressing potential users with innovation; more available information, and also recognise the need to highlight economic benefits. In addition, perhaps, using more cultural symbols, packaging and also mobilising the energies of socio-religious movement while dealing with systemic change (Pastakia 1998). These could, perhaps, become a key issues for more sustainable entrepreneurship.

\section{Research Methodology}

The present study was designed to combine qualitative and quantitative approaches. Primary and secondary data are used. A triangulation technique (interview, survey and observation) was employed to ensure greater confidence in the findings (Othman 2007). In-depth interviews and surveys by using semi-structured questionnaires were conducted for data collection.

SWOT analysis also used to analyze interviews result on entrepreneurs. SWOT analysis consists of four quadrants. Internal survey was used to highlight the strength and weakness. Meanwhile, the external survey was used to look at the opportunities and threats faced by entrepreneurs in developing straw as a competitive agribusiness (David 1989; Ku Amir n.d.). 
Studies were undertaken on entrepreneurs that use rice straw as a raw material in their business. A sample of 24 entrepreneurs was chosen from the MADA region, Kedah and 20 entrepreneurs in Sekinchan. The sample emerged from searching websites and from recommendations made by entrepeneurs already identified. Sekinchan is located in the Integrated Agricultural Development Area (IADA) of North-West Selangor. These are the two major granary areas in Malaysia.

\section{Results and Discussion}

\subsection{Entrepreneurs' Profiles}

This study consists of seven types of enterprises offering a wide range of different agribusiness, giving a wider understanding of the barriers and challenges that require addressing (Table 1).

Table 1. Type of enterprise using straw as raw material in agribusiness development

\begin{tabular}{lcccc}
\hline \multirow{2}{*}{ Type of enterprise } & \multicolumn{2}{c}{ MADA region, Kedah } & \multicolumn{2}{c}{ Sekinchan, Selangor } \\
\cline { 2 - 5 } & Frequency $(\mathrm{n}=24)$ & Percentage (\%) & Frequency $(\mathrm{n}=20)$ & Percentage $(\%)$ \\
\hline Livestock feed & 9 & 37.5 & 6 & 30.0 \\
Compost & 6 & 25.0 & 9 & 45.0 \\
Craft paper making & 4 & 16.6 & - & - \\
Mushroom growth medium & 3 & 12.5 & 3 & 15.0 \\
Power plant energy & 1 & 4.2 & - & - \\
Nursery mat & 1 & 4.2 & 1 & 5.0 \\
Erosion control mat & - & - & 1 & 5.0 \\
\hline
\end{tabular}

The age range of entrepreneurs is between 31 to 40 years old. Almost, all of the entrepreneurs surveyed had finished their secondary school in the Malaysian Certificate of Education level and above. The study found that a few enterpreneurs have more than 16 years of using straw as a raw material in their agribusiness. Some of them were farmers, and using straw as compost in rice cultivation. While the rest of the farmers were using straw for livestock feeding. Most entrepreneurs, especially in craft paper-making and compost-making, had previous experience of less than 15 years (Table 2).

Table 2. Entrepreneurs' demographic profile

\begin{tabular}{|c|c|c|c|c|}
\hline \multirow{2}{*}{ Demographic profile } & \multicolumn{2}{|c|}{ MADA region, Kedah $(n=24)$} & \multicolumn{2}{|c|}{ Sekinchan, Selangor $(\mathrm{n}=20)$} \\
\hline & Total & Percentage & Total & Percentage \\
\hline \multicolumn{5}{|l|}{ Age } \\
\hline Less than 20 years & - & - & - & - \\
\hline $21-30$ years & 4 & 16.7 & 3 & 15.0 \\
\hline $31-40$ years & 9 & 37.5 & 7 & 35.0 \\
\hline $41-50$ years & 6 & 25.0 & 6 & 30.0 \\
\hline More than 51 years & 5 & 20.8 & 4 & 20.0 \\
\hline \multicolumn{5}{|l|}{ Education level } \\
\hline Not in school & - & - & - & - \\
\hline Primary school & 1 & 4.2 & - & - \\
\hline LCE/ SRP & 2 & 8.3 & 4 & 20.0 \\
\hline MCE/ SPM & 13 & 54.2 & 11 & 55.0 \\
\hline HSC/ STPM & 3 & 12.5 & 2 & 10.0 \\
\hline Certificate/Diploma/Degree & 5 & 20.8 & 3 & 15.0 \\
\hline \multicolumn{5}{|c|}{ Duration of using straw in agribusiness } \\
\hline Less than 5 years & 5 & 20.8 & 9 & 45.0 \\
\hline $6-10$ years & 11 & 45.8 & 5 & 25.0 \\
\hline $11-15$ years & 2 & 8.3 & 3 & 15.0 \\
\hline $16-20$ years & 3 & 12.5 & 1 & 5.0 \\
\hline More than 21 years & 3 & 12.5 & 2 & 10.0 \\
\hline
\end{tabular}

*Note: LCE/ SRP: Lower Certificate of Education/ Sijil Rendah Pelajaran, MCE/ SPM: Malaysian Certificate of Education/ Sijil Pelajaran Malaysia , HSC/ STPM: Malaysia Higher School Certificate/ Sijil Tinggi Pelajaran Malaysia

\subsection{Barriers and Challenges of Rice Straw Agribusiness Development}

Several issues were identified that hinder potential entrepreneurs to develop straw agribusiness (Table 3). 
Table 3. Entrepreneurs' barriers and challenges in straw agribusiness development

\begin{tabular}{lcccc}
\hline \multirow{2}{*}{ Barriers and challenges in straw agribusiness development } & \multicolumn{3}{c}{ MADA region, Kedah $(\mathrm{n}=24)$} & \multicolumn{2}{c}{ Sekinchan, Selangor $(\mathrm{n}=20)$} \\
\cline { 2 - 5 } & Yes (\%) & No (\%) & Yes (\%) & No (\%) \\
\hline Lack of institutional support & $20(83.3)$ & $4(16.7)$ & $14(70.0)$ & $6(30.0)$ \\
Lack of grassroot or community support & $19(79.2)$ & $5(20.8)$ & $18(90.0)$ & $2(10.0)$ \\
Lack of research and access to technology facilities & $17(70.8)$ & $7(29.2)$ & $17(85.0)$ & $3(15.0)$ \\
Lack of relevant skills and knowledge & $14(58.3)$ & $10(41.7)$ & $16(80.0)$ & $4(20.0)$ \\
Lack of capital & $13(54.2)$ & $11(45.8)$ & $13(65.0)$ & $7(35.0)$ \\
Lack of enterprising spirit & $10(41.7)$ & $14(58.3)$ & $11(55.0)$ & $9(45.0)$ \\
Limited product range in the market & $9(37.5)$ & $15(62.5)$ & $10(50.0)$ & $10(50.0)$ \\
Unreliable supply of raw straw & $5(20.8)$ & $19(79.2)$ & $5(25.0)$ & $15(75.0)$ \\
Lack of skilled workers & $4(16.7)$ & $20(83.3)$ & $3(15.0)$ & $17(85.0)$ \\
\hline
\end{tabular}

\subsubsection{Lack of Institutional Support}

Government policies significantly affect entrepreneurship development by changing rules and regulations in different institutional environments (Lee et al. 2013). Institutions can play a crucial role in enforcing policies; improving technology; generating investment; creating infrastructure, and in promotion and the marketing of new products (Lee et al. 2013). This requires proper documentation and systematic strategies. Strong support services should also be strengthened as a result, in influencing supply and demand for straw by-products.

Most of the present entrepreneurs strongly agreed that less support services from government institutions or appropriate authority is key in causing some stagnation in straw agribusiness. It was stated by $83.3 \%$ entrepreneurs in the MADA region and $70.0 \%$ in Sekinchan (Table 3). Interviews revealed that institutions only see straw as a small contributory effort to reduce straw open burning; air pollution and reducing the cost of field management. The policy in Malaysia for straw management and utilisation only mainly exists indirectly as a result of the main agricultural byproducts-use policy, such as palm oil and rubber. Therefore, only a small amount of funding support allocation is disbursed by government for straw development. In addition, it seems that only some poorly trained officers are mostly available to guide entrepreneurs to improve product quality. Weaknesses in promotions from other institution also affect more widespread straw by-products in the market place.

\subsubsection{Lack of Grassroot or Community Support}

Interviews revealed that community support is very important in increasing demand for straw products. Beyond the weaknesses in promotions, the potential in using straw products is not being communicated to consumers. The community has a lack of awareness and sensitivity to the potentially environmentally-friendly products, as strongly agreed by the 19 respondents (79.2\%) in the MADA region and 18 respondents (90.0\%) in Sekinchan. As a result, this lack of demand has led the straw products market to grow only very slowly.

According to the compost entrepreneurs, most farmers do not know the potential and advantages of using straw compost compared to chemical fertilizer. Even though straw compost has proved particularly useful in stabilizing soil structure; storing and recycling nutrients; in encouraging micro-organism activity, and also enhancing agronomic productivity particularly in the long term (Lal 2005; Matsumura et al. 2005). But, chemical fertilizer is more easily obtained in the market instead of straw compost, and easier to apply often.

All of the entrepreneurs strongly agreed that straw crafts only attract customers from urban communities instead of rural communities. Rural inhabitants assume that straw craft is not unique because it is produced from readily-available crop residue around their neighbourhood. However, in urban communities, straw craft products can and does get attention among the more prominent people, the hotel industry and shopping malls as a craft decoration. In addition, straw craft products have a higher demand from some foreign markets, because they are more aware and appreciative of such environmentally-friendly products. It is not surprising, therefore, that a straw craft products seems more favourable for overseas markets than for local outlets.

\subsubsection{Lack of Research and Access to Technology Facilities}

The survey shows that lack of research and access to technology facilities are also currently a big challenge to success in straw business. This was recognized by $70.8 \%$ of entrepreneurs in the MADA region and $85.0 \%$ in Sekinchan (Table 3). Interviews with compost entrepreneurs found that to produce straw compost manually takes time, of usually at least three months to decay. Straw needing to be turned upside down regularly, and the process is very labour intensive. Furthermore, the temperature is very hot up to $70^{\circ} \mathrm{C}$ for the occurrence of suitable urea processes (MADA 2010). This is burdensome for workers to produce compost manually and may also be uneconomic. 
To deal with the absence of high quality machinery and technology, most craft paper processing must also be done manually. Straw paper production involves several processes including the clean-up of straw; cutting or grinding; filtration; compression and drying (Nas Norziela 2010). Interviews revealed that entrepreneurs at the Kedah State Handicrafts Incubator Center, for example, producing handmade straw paper takes substantial preparation time. Limitations include too little machinery, which also has to be shared. The grinder provided was also too small, and needed to be done repeatedly to process a lot of straw capacity. In addition, entrepreneurs have to share with others, and sometimes need to wait for two or three hours. The paper compressor provided also had to be shared, and was not capable of drying the paper immediately. However, the paper will dry naturally in the room temperature depending on weather conditions. These limitations adversely affect straw craft production and also the enthusiasm of those involved.

Poor research in straw quality makes it impossible to compete with other products both locally as well as internationally. Straw paper products such as paper bags, gift wrapping and key chains are fragile and can be easily torn when it is wet due to water. Consequently, entrepreneurs lose their product demand due to poor innovation, with such inappropriate items.

Demand for rice straw as cattle feed also remains low. Straw is given as a supplement only because of high fiber, but does not provide sufficient mineral content for cattle growth (Rosmiza et al. 2014; Devendra 1989). Research and development of straw as a substrate in mushroom cultivation also needs more improvement. Interviews with one of mushroom entrepreneurs revealed, based on her experience, that imported straw from Thailand can produce a better quality mushroom than locally-produced straw. This may perhaps be due to the using of chemical fertilizers and pesticides during more intensive rice cultivation in Malaysia. The chemicals in rice straw having adverse effects for mushroom cultivation. This contrast with farmers in Thailand, that are practising more organic farming perhaps. Importing straw would also increase the costs, even though it is found easily and cheaply around the local granary area, and importing straw is very unlikely to be as economic.

\subsubsection{Lack of Relevant Skills and Knowledge}

Interviews revealed that entrepreneurs get basic skills and knowledge of straw as an agribusiness from three sources. There is institution support; informal learning through friends experiences, and existing knowledge. Institutions sometimes provide a workshop demonstrating successful entrepreneurial activity, production techniques, processing systems, and social development programmes to try to create a more dynamic and competitive enterprise development. Interviews found that all entrepreneurs had received advice and attended courses or seminars organized by these institutions. Several entrepreneurs also obtained help with supporting machinery, workshops and sheds. However, interviews revealed entrepreneurs still lack confidence to compete in the market. They still need continuous advice and more appropriate training from institutions in Malaysia.

Gaining skills and creativity, the Malaysian Handicraft Development Corporation Kedah branch also provide tours and exibitions both locally and internationally such as in the Philippines, Hong Kong and Indonesia to craft entrepreneurs. According to the participants, involvement in this support programme is very effective in boosting knowledge and the sharing of ideas. Also in creating new innovations in processing techniques for straw craft products, in learning from elsewhere. It is also a promotional opportunity to create wider business networks. One of the craft entrepreneurs stated that demand for her product was now widespread in many countries, and the business income had increased fourfold after participating in such international exibitions.

\subsubsection{Lack of Capital}

As a new venture with shallow experience in business, entrepreneurs sometimes face hindrances of accessing loan and finance from institutions. More than half of entrepreneurs in the study area faced a shortage of capital to expand their straw business (Table 3). Investment does not happen in the short term as a demand may be slow in the market. Furthermore, the craft is not usually a consumer daily product and the demand is mostly intermittent. Due to difficulties in accessing credit, they use their own capital, and take more time to get back their return on capital to generate any future profitability.

One craft entrepreneur stated that innovation requires further technology and more materials. The cost of production are higher due, for example, to using a new technique such as marbling and 'batik canting'. These innovations use laser techniques and high quality colour. To make the straw products more valuable, packaging materials must also be more attractive. For global markets, straw craft products require a high quality of packaging to prevent damage. Interviews revealed that lack of capital inhibits entrepreneurs from competing in global markets. Based on craft entrepreneurs experience, shipping with poor quality packaging has previously led to many products becoming 
damaged. Clients lost confidence, and as a result, the entrepreneurs suffer losses. He also noted that export demand usually involved a large capacity of products which provides 5000 to 10,000 straw crafts, for example, a month and a minimum supply of three years. As a result of the high cost of packaging, shipping and export tax, entrepreneurs only tend to focus mostly on local markets and on a smaller business scale.

For compost and livestock enterprise, capital is needed to build a proper straw storage facility with a roof and wide area. Sensitivity to humidity causes straw to easily become mouldy when exposed to dew and rain (Rosmiza et al. 2014). Lack of capital for providing such basic facilities has sometimes deterred entrepreneurs from expanding their straw agribusiness.

\subsubsection{Lack of Enterprising Spirit}

Interviews also identified that some entrepreneurs were uninformed in developing new straw business as another factor that has led to stagnation in agribusiness development. They cannot afford, reportedly, to act more aggressively promoting straw products individually. Such entrepreneurs often relying mostly on financial support and promotion from government.

Observation shows that entrepreneurs are also less willing to enter new markets, especially local markets. They produce the same product. So, the straw craft market is seen to be limited to local markets and certain local communities only. Entrepreneurs do not seems to be looking for more variety in greatly enlarging the market. As a result, their business profitability is limited and declining.

One of the craft entrepreneurs stated that an entrepreneur's age may also cause them to be less creative in contributing ideas and design of products. They are not so sensitive to design new exciting products for current or future needs. Their ideas are common and widely available in the market such as key chains and catchphrases. While, the young entrepreneurs are more advanced in shaping ideas and product design. Young entrepreneurs also get some innovation ideas and the latest design through the internet and reading. Only a few entrepreneurs stated that they were not sufficiently confident to penetrate international markets due to language problem (especially English language) in communicating with foreign investors. However, interviews revealed that three entrepreneurs had such a vision and high motivation to improve their business. They took their own initiatives abroad to Singapore, Indonesia, Thailand, and California in the United States.

\subsubsection{Limited Product Range in the Market}

Findings also show that the limited straw products available for the market has also affected the development of straw agribusiness. This was strongly agreed by $37.5 \%$ of entrepreneurs in the MADA region and $50.0 \%$ in Sekinchan (Table 3 ). Observations reveal that straw craft products can be limited to a certain community and religion. All craft entrepreneurs produce the same product such as the Malay wedding box, Islamic calligraphy and keychains. Hence, the market will be limited and not widespread to other races of people in Malaysia. Products also do not attract interest and demand from rural communities, and have also failed to impress the corporate sector. This in turn affects market performance.

\subsubsection{Unreliable Supply of Raw Straw}

Interviews revealed that the supply of straw raw material has less of an effect on straw agribusiness. This was strongly agreed by $79.2 \%$ of entrepreneurs in the MADA region and $75.0 \%$ in Sekinchan (Table 3). Straw is very widely available throughout Kedah and Sekinchan area. It is available in two seasons per year, and there is also a continuous supply from straw storage.

For example, in the MADA region, most of entrepreneurs get straw from the District Farmer's Organisation or Pertubuhan Peladang Kawasan (PPK). The price for a straw bale weighing $145 \mathrm{~kg}$ is currently about RM80 (Malaysian Ringgit) including delivery and RM70 without delivery. However, some entrepreneurs sometimes face the problem of getting sufficient quantities of straw supplies to run their business. This is because the storage nearby is insufficient to meet the demand for animal feeding, compost and other uses from local and other areas. PPK try to get the straw from other areas, therefore, which are located some distance away. This situation adversely affects straw agribusiness development. However, most of the livestock entrepreneurs are also farmers, and obtain straw for livestock feeding from their own's field.

Interviews revealed that craft entrepreneurs only use small quantities of straw. Usually, they get their own straw supply from a farmer at a lower price between 50 cents to RM2.00 per sack, and sometimes for free. This is due to farmers considering straw mostly as a waste residue, needing to be cleared-up for another season. 


\subsubsection{Lack of Skilled Workers}

Results indicate that entrepreneurs never have a problem in getting permanent or part-time workers, as reported by 83.3\% entrepreneurs in the MADA region and $85.0 \%$ in Sekinchan (Table 3). Usually, local labour comes from secondary school leavers and houseviwes.

Craft entrepreneurs stated, however, that they have difficulty obtaining more skilled workers. Most temporary workers are housewives, and just gaining an extra income. They lack skills and ideas; have reported low quality of work; are not efficient in terms of production; and have no initiative to improve themselves by attending skills courses. As a result, the end product sometimes seems unattractive; untidy and unable to fulfill the expectation orders. Customers, as a result, are becoming less confident with their products and sometimes have to bear the loss of cancelled orders.

\subsection{SWOT Analysis of Challenges facing Rice Straw Agribusiness Development}

A SWOT analysis was conducted based on the reported results obtained. There are seven strengths that need to be highlighted, with consideration of two significant opportunities for greater benefit. Whereas, seven scores of weaknesses and four scores of threats must also be fully addressed (Table 4).

Table 4. SWOT analysis of challenging developing rice straw in agribusiness

Straw is widely and abundant
Straw price is cheap

\section{Conclusion}

Overall, this research has revealed that entrepreneurs struggle to expand their business especially due to lack of support from government and the public; research; innovation; capital and skilled workers. Entrepreneur characteristics can include a failure to understand the opportunities and potential of developing value chains for domestic and international market needs. The crucial challenges in straw agribusiness development relate to both on-field and off-field uses, and economically viable options of products for more market-driven opportunities. Encouraging entrepreneurship in a sustainability context will require a more thoughtful approach. Supporting strategies from institutions; capital markets for finance and investment; stakeholder and community interest; and the development of entrepreneurs themselves remain critical.

The following might be considered to support more sustainable straw agribusiness development in Malaysia:

- Improved policy and regulation for straw burning.

- Introduction of a subsidy for rice straw products such as compost and livestock feeding.

- The provision of more research grants for research, technology acquisition, and innovation to enhance competitiveness on straw development of processes and new products.

- More financial resources for agribusiness entrepreneurs such as grants, direct commercial loan, loan guarantees and low interest loan.

- Boosting promotion efforts by state agencies.

- The provision of more training courses to boost more entrepreneurial skills and knowledge. 


\section{Acknowledgements}

Financial support by the Ministry of Education Malaysia for post doctoral studies at the Royal Agricultural University, Cirencester, United Kingdom and a grant from Universiti Kebangsaan Malaysia (Grant No.: GGPM 2013-041).

\section{References}

Ahammad I., \& Syed Moudud-Ul- Huq. (2013). Women entrepreneurship development In Bangladesh challenges and prospects. International Journal of Innovative Research and Development, 2(7), 41-48.

Ahmad S. Z., \& Xavier S. R. (2012). Entrepreneurial environments and growth: evidence from Malaysia GEM data. Journal of Chinese Entrepreneurship, 4(1)1, 50-69.

Bergh L. (2013). Sustainability-driven entrepreneurship: perceptions of challenges and obstacles in a South African context. (Master thesis). University of Cambridge.

Bhattacharya S. C. (2002). Biomass energy in Asia: A review of status, technologies and policies in Asia. Energy for Sustainable Development, 2, 5-10.

Bijay-Singh, Shan Y. H., Johnson-Beebout S. E., Yadvinder-Singh, \& Buresh R. J. (2008). Crop residue management for lowland ricebased cropping systems in Asia. Advances in Agronomy, 98, 117-187.

Chowdhury M. S., Alam Z., \& Arif M. I. (2013). Success factors of entrepreneurs of small and medium sized enterprises: Evidence from Bangladesh. Business and Economic Research, 3 (2), 38-52.

David F. R. (1997). Strategic Management. London: Prentice Hall.

Devendra C. (1989). Crop residues for feeding animals in Asia: technology development and adoption in crop/livestock systems. [Online] Available: http://www.ilri.org. (February 22, 2015).

Gupta R. K., \& Garg S. C. (2004). Residue burning in rice-wheat cropping system: causes and implications. Current Science, 87 (12), 1713-1717.

Henderick P., \& Williams R. H. (2000). Trigeneration in a Northern Chinese village using crop residues. Energy for Sustainable Development, 4(3), 26-42.

Herrington M., \& Kew, J. (2013). GEM 2013 South African report: twenty years of democracy. University of Cape Town: South Africa.

Indian Agricultural Research Institute. (2012). Crop residues management with conservation agriculture: Potential, constraints and policy needs. New Delhi: Indian Agricultural Research Institute.

Keogh P. D., \& Polonsky M. J. (1998). Environmental commitment: a basis for environmental entrepreneurship?. Journal of Organizational Change, 11(1), 38-49.

Ku Amir Ku Daud. [n.d.]. Analisis SWOT. [Online] Available: http://www.unimap.edu.my/images/Analisis_SWOT\% [January 15, 2015).

Lal R. (2005). World crop residues production and implications of its use as a biofuel. Environment International, 31, 575-584.

Lee S., Peng M.W., \& Song S. (2013). Governments, entrepreneurs, and positive externalities: a real options perspective. European Management Journal, 31, 333-347.

Matsumura Y., Minowa T., \& Yamamoto H. (2005). Amount, availability, and potential use of rice straw (agricultural residue) biomass as an energy resource in Japan. Biomass and Bioenergy, 29, 347-354.

Ministry of Economic Affairs. (2013). Rice straw and wheat straw. Potential feedstocks for the Biobased Economy. [Online] Available: http://edepot.wur.ul (January 7, 2015).

Muda Agricultural Development Authority (MADA). (2004). Business plan: projek jerami dan kompos di Kawasan Muda (Business plan: straw and compost project in Muda Region). Alor Setar: Kedah.

Nas Norziela Nasbah. (2010). Jerami padi 'jadi duit' (Rice straw 'makes money') [Online] Available: http://www.utusan.com.my (1 January 2015).

Othman Lebar. (2007). Penyelidikan kualitatif: pengenalan kepada teori dan metod. Tanjong Malim: Penerbit Universiti Pendidikan Sultan Idris.

Pastakia A. (1998). Grassroots ecopreneurs: change agents for a sustainable society. Journal of Organizational Change Management, 11(2), 157-173.

Rofina Yasmin Othman \& Subha Bhassu. (n.d.). The role of biotechnology in sustainable agriculture for the future. [Online] Available: http://ensearch.org (May 5, 2015).

Rosmiza M. Z., Davies W. P., Rosniza Aznie C. R., Mazdi M., \& Jabil M. J. (2014). Farmers' knowledge on potential uses of rice straw: an assessment in MADA and Sekinchan, Malaysia. Geografia Malaysian Journal of Society and Space, 5, 30-43.

Rosmiza M. Z., Davies W. P., Rosniza Aznie C. R., Mazdi M., Jabil M. J., Wan Toren W. Y., \& Che Rosmawati C. M. (2014). Farmers' participation in rice straw-utilisation in the MADA region of Kedah, Malaysia. Mediterranean Journal of Social Sciences, $5(23)$, 229-237.

Uddin R., \& Bose T. K. (2013). Motivation, success factors and challenges of entrepreneurs in Kulna City of Bangladesh. European Journal of Business and Management, 5(16), 148-156.

Vianaa M., Lo' peza J.M., Querola X., Alastueya A., García-Gaciob D., Blanco-Herasb G., Lo’ pez-Mahı́ P., Piñ eiro-Iglesiasc M., Sanzd M. J., Sanzd F., Chie X., \& Maenhaute M. (2008), Tracers and impact of open burning of rice straw residues on PM in Eastern Spain. Atmospheric Environment, 42, 1941-1957.

World Bank. (2013). Growing Africa: Unlocking the potential of agribusiness.

Zhang R., Jenkins B.M. (2004). Commercial uses of straw. Agricultural Mechanization and Automation, Vol II. California: USA. 